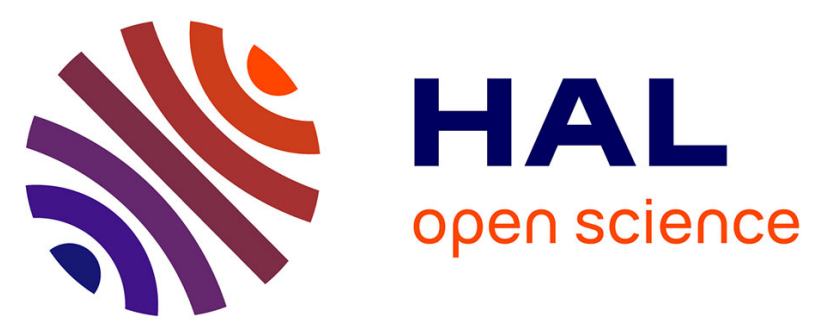

\title{
Location and chemical composition of microbially induced phosphorus precipitates in anaerobic and aerobic granular sludge
}

Angela Manas, Mathieu Sperandio, François Decker, Béatrice Biscans

\section{To cite this version:}

Angela Manas, Mathieu Sperandio, François Decker, Béatrice Biscans. Location and chemical composition of microbially induced phosphorus precipitates in anaerobic and aerobic granular sludge. Environmental Technology, 2012, vol. 33 (19), pp.2195-2209. 10.1080/09593330.2012.696719 . hal00762274

\section{HAL Id: hal-00762274 \\ https://hal.science/hal-00762274}

Submitted on 15 Mar 2013

HAL is a multi-disciplinary open access archive for the deposit and dissemination of scientific research documents, whether they are published or not. The documents may come from teaching and research institutions in France or abroad, or from public or private research centers.
L'archive ouverte pluridisciplinaire $\mathbf{H A L}$, est destinée au dépôt et à la diffusion de documents scientifiques de niveau recherche, publiés ou non, émanant des établissements d'enseignement et de recherche français ou étrangers, des laboratoires publics ou privés. 


\title{
Location and chemical composition of microbially induced phosphorus precipitates in anaerobic and aerobic granular sludge
}

\author{
A. Mañas ${ }^{\mathrm{a}, \mathrm{b}, \mathrm{c}, \mathrm{e}}$, M. Spérandio ${ }^{\mathrm{a}, \mathrm{b}, \mathrm{c} *}$, F. Decker ${ }^{\mathrm{d}}$ and B. Biscans ${ }^{\mathrm{e}}$ \\ ${ }^{a}$ INSA, UPS, INP, LISBP, Université de Toulouse, Toulouse, France; ${ }^{b}$ INRA, Ingénierie des Systèmes Biologiques \\ et des Procédés, Toulouse, France; ${ }^{c}$ CNRS, Toulouse, France; ${ }^{d}$ VALBIO, Toulouse, France; \\ ${ }^{e}$ CNRS, Laboratoire de Génie Chimique, Toulouse, France
}

\begin{abstract}
This work focuses on combined scanning electron microscopy and energy dispersive X-ray analysis (SEM-EDX) applied to granular sludge used for biological treatment of high-strength wastewater effluents. Mineral precipitation is shown to occur in the core of microbial granules under different operating conditions. Three dairy wastewater effluents, from three different upflow anaerobic sludge blanket (UASB) reactors and two aerobic granular sequenced batch reactors (GSBR) were evaluated. The relationship between the solid phase precipitation and the chemical composition of the wastewater was investigated with PHREEQC software (calculation of saturation indexes). Results showed that $\mathrm{pH}, \mathrm{Ca}: \mathrm{P}$ ratios and biological reactions played a major role in controlling the biomineralization phenomena. Thermodynamics calculations can be used to foresee the nature of bio-precipitates, but the location of the mineral concretions will need further investigation as it is certainly due to local microbial activity.
\end{abstract}

Keywords: anaerobic granules; aerobic granules; UASB; dairy wastewater; biomineralization; microbially induced precipitation

\section{Introduction}

Nitrogen and phosphorus are responsible for eutrophication, which affects more than $50 \%$ of lakes and reservoirs worldwide [1]. High-strength wastewaters generated by the agro-food industry contribute significantly to this phenomenon. Because of its high biodegradable-organic content, this type of wastewater is an ideal candidate for intensive biological treatment based on granular sludge, either anaerobic or aerobic [2]. Upflow anaerobic sludge blanket (UASB) reactors based on granular sludge have been reported to be robust, efficient systems for reducing the high organic loads that the agro-food industry produces [3]. However, anaerobic digestion is not effective for nutrient removal and should be followed by a process dealing with nitrogen and phosphorus. Anaerobic effluents are rich in ammonium due to the hydrolysis of proteins, and need further treatment by conventional biological nitrification/denitrification or by partial nitrification combined with the Anammox process. Precipitation of phosphorus in the form of struvite (magnesium ammonium phosphate) is feasible in a crystallizer reactor with reagent dosing. $\mathrm{MgCl}_{2}$, $\mathrm{MgOH}$ or $\mathrm{NaOH}$ are usually required in specific crystallization reactors for struvite precipitation because dairy wastewater effluents are usually deficient in $\mathrm{Mg}^{2+}$ compared with $\mathrm{NH}_{4}^{+}$or $\mathrm{PO}_{4}^{3-}$. In our case, $\left[\mathrm{Mg}^{2+}\right]$ in dairy effluents was between $10-20 \mathrm{mg} / \mathrm{L}$. Considering that, for struvite precipitation, the stoichiometry is $1 \mathrm{~mol} \mathrm{Mg}^{2+}$ to $1 \mathrm{~mol}$ of $\mathrm{NH}_{4}^{+}$and $1 \mathrm{~mol}$ of $\mathrm{PO}_{4}^{3-}$, the lack of $\mathrm{Mg}^{2+}$ limits the precipitation of struvite relative to other phosphate minerals. Thus reagents are used because effluents are usually deficient in $\mathrm{Mg}$ and strict control of the $\mathrm{pH}$ is required [4]. Aerobic granular sludge in sequenced batch reactors (GSBR) has been developed more recently, and it has proved its ability to withstand high organic loads and perform simultaneous nitrogen and phosphorus removal $[5,6]$. For example, biological phosphorus removal was successfully performed in a granular sludge process treating effluent from a slaughterhouse [7].

Since industrial wastewaters also contain significant amounts of dissolved salts, precipitation can be observed in granular sludge processes. On the one hand, solid precipitation can be disadvantageous for granular sludge as it can reduce biological activities, increase the energy needs for mixing, and clog pipes $[8,9]$. On the other hand, phosphate precipitation can constitute a removal process functioning in synergy with biological P removal [10]. Hence, for different positive and negative reasons, these processes need to be controlled and predicted as accurately as possible. Both types of granules (aerobic and anaerobic) consist of macroaggregates made up of a wide range of different bacterial

\footnotetext{
*Corresponding author. Email: sperandio@insa-toulouse.fr
} 
consortia, which can induce local $\mathrm{pH}$ and ion concentration gradients, leading to mineral precipitation inside the granules [11,12]. A variety of analytical techniques (Raman spectroscopy, scanning electron microscopy and energy dispersive X-ray analysis (SEM-EDX), X-ray diffraction and chemical extractions) have been applied to aerobic granules from a GSBR. They revealed that calcium phosphate precipitated inside granules in the form of hydroxyapatite $\left(\mathrm{Ca}_{5}\left(\mathrm{PO}_{4}\right)_{3}(\mathrm{OH})\right)$, causing up to $46 \%$ of the total $\mathrm{P}$ removal in the process [13]. Calcium carbonate precipitation inside aerobic granules has also been demonstrated with SEM-EDX analysis [14-16], but little information on its formation and location is provided in the literature. In the field of anaerobic granules, Langerak investigated the parameters that could control the location of calcium carbonate either in the liquid phase or in the microbial biofilm of the granules [17].

Precipitation of phosphate minerals has been mainly investigated through analyses of the ash content of granular sludge but, as far as we know, no exhaustive local or chemical analyses have been conducted $[8,17,18]$. Moreover, the prediction of this phenomenon using geochemical models and a thermodynamic database for precipitation has not yet been evaluated. Knowledge of the biomineralization phenomena inside granules and their further control is also important regarding the value-added use of sludge, as well as the long-term stability of UASB and GSBR, which is a problematic issue in these processes.

Therefore, this work is specifically dedicated to the study of the solid mineral compounds found in granular sludge processes (aerobic and anaerobic) applied in highstrength wastewater treatment. A set of characterization analyses was carried out on different granule samples collected in different anaerobic (UASB) or aerobic (GSBR) processes treating dairy or synthetic wastewaters, respectively. The nature and location of the bio-precipitation process was investigated and its pros and cons will be pointed out. In an attempt to explain how the supernatant conditions can affect bio-precipitation, the characteristics of the wastewaters were analysed extensively and PHREEQC modelling software was used to calculate the saturation indexes (SI) of the minerals involved.

\section{Materials and methods}

\subsection{Solid characterization and sample preparation}

Anaerobic granule samples from three different UASB reactors treating wastewaters produced by cheese factories in southern France were studied. They are referred to as industrial sites 1, 2 and 3. Anaerobic granules came from the anaerobic digester mixed liquor separated from the supernatant by settling $(5 \mathrm{~min})$. No purge was made between start-up and the time granule samples were taken; hydraulic retention times (HRTs) were 5, 5 and 2.6 days and organic loading rates (ORLs; $\mathrm{kgCOD} \mathrm{m}^{-3} \mathrm{~d}^{-1}$ ) were $8.5,8$ and $8 \mathrm{kgCOD} \mathrm{m}^{-3} \mathrm{~d}^{-1}$ for sites 1,2 and 3, respectively.

Aerobic granules were sampled from two different GSBR processes (at the end of the aerobic reaction phase) fed with synthetic wastewater. Granular sludge had been inoculated more than 1 year before sampling, and the processes were operated for more than 100 days with different operating conditions: in anoxic/aerobic batch cycles for Laboratory_R1 and anaerobic/aerobic cycles for Laboratory_R2. The latter was seeded from R1 for quick start-up, as described elsewhere [19]. OLRs and HRT were identical in both aerobic reactors: $3 \mathrm{KgCOD} \mathrm{m}^{-3} \mathrm{~h}^{-1}$ and $8.5 \mathrm{~h}$, respectively. GSBR cycles were composed of a $15 \mathrm{~min}$ feeding, 20 min anoxic or anaerobic (mixed with nitrogen gas blowing) period, a $145 \mathrm{~min}$ aerobic period, $30 \mathrm{~min}$ settling and $30 \mathrm{~min}$ withdrawal. More details concerning the reactor operating conditions can be found elsewhere [11]. Granules were classified according to their size and colour, as described in Iqbal Bhatti et al. [18]. Granule samples are shown in Figure 1, and Table 1 summarizes their characteristics. Owing to the great heterogeneity of granules from industrial sites (different colours and sizes), three granules were analysed for each type of aggregate according to their colour: grey, brown, black or white. Conversely, aerobic granules were homogeneous and more than 10 granules were collected from each aerobic reactor, showing

(a)

(b)

(c)

(d)

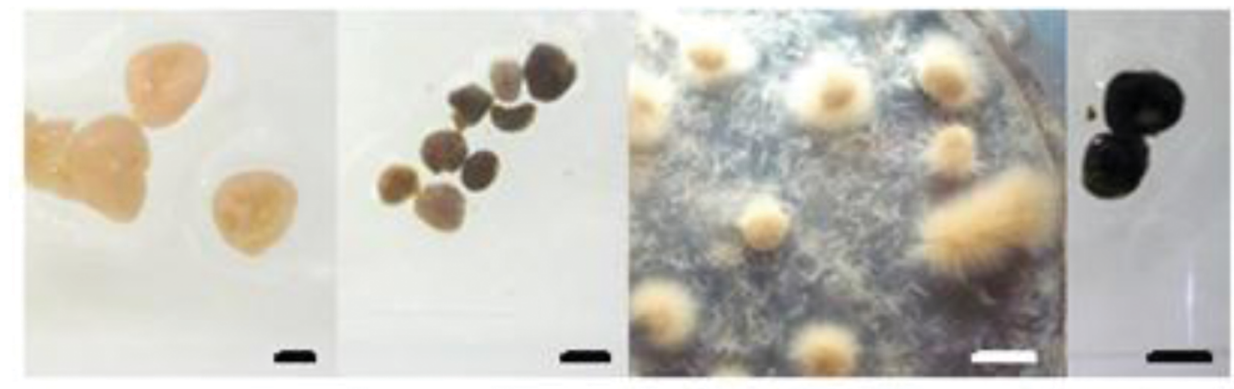

Figure 1. Images of the different granules sampled from: a) GSBR Laboratory_R1; b) UASB Industrial Site 1; c) GSBR Laboratory_R2; d) UASB Industrial Site 3 . Scale bar $=2 \mathrm{~mm}$ length. 
Table 1. Classification of the granules sampled.

\begin{tabular}{|c|c|c|c|c|c|}
\hline Sample name & Site & Condition & $\begin{array}{c}\text { Diameter } \\
\left(\mathrm{D}_{G}, \mathrm{~mm}\right)\end{array}$ & Color & $\begin{array}{l}\text { Legend in } \\
\text { Figure } 2\end{array}$ \\
\hline $\mathrm{S} 1 \_$ana $\# 01$ & \multirow[t]{5}{*}{ Industrial Site 1 UASB } & \multirow[t]{5}{*}{ Anaerobic } & 3.1 & white & $2 \mathrm{a}$ \\
\hline $\mathrm{S} 1$ _ana\#02 & & & 2.7 & white & $2 b$ \\
\hline $\mathrm{S} 1$ _ana\#03 & & & 2.5 & grey & $2 \mathrm{c}$ \\
\hline $\mathrm{S} 1$ _ana\#04 & & & 1.2 & brown & $2 d$ \\
\hline $\mathrm{S} 1$ _ana $\# 05$ & & & 2.6 & black & $2 \mathrm{e}$ \\
\hline $\mathrm{S} 2$ _ana\#06 & \multirow[t]{3}{*}{ Industrial Site 2 UASB } & \multirow[t]{3}{*}{ Anaerobic } & 1.6 & brown & $2 f$ \\
\hline S2_ana\#07 & & & 3.1 & grey & $2 g$ \\
\hline S2_ana $\# 08$ & & & 3.4 & black & $2 \mathrm{~h}$ \\
\hline S3_ana\#09 & \multirow[t]{3}{*}{ Industrial Site 3 UASB } & \multirow[t]{3}{*}{ Anaerobic } & 4.0 & grey & $2 \mathrm{i}$ \\
\hline $\mathrm{S} 3$ _ana\#10 & & & 2.1 & grey & $2 \mathrm{j}$ \\
\hline S3_ana\#11 & & & 2.5 & black & - \\
\hline $\mathrm{S} 4$-aer\#12 & \multirow[t]{3}{*}{ Laboratory_R1 GSBR } & \multirow[t]{3}{*}{ Alternating anoxic/aerobic } & 2.4 & brown & $2 \mathrm{k}$ \\
\hline S4_aer\#13 & & & 1.2 & brown & 21 \\
\hline S4_aer\#14 & & & 1.5 & brown & $2 \mathrm{~m}$ \\
\hline S5_aer\#15 & \multirow[t]{3}{*}{ Laboratory_R2 GSBR } & \multirow[t]{3}{*}{ Alternating anaerobic/aerobic } & 3.7 & brown & $2 n$ \\
\hline S5_aer\#16 & & & 2.8 & brown & 20 \\
\hline S5_aer\#17 & & & 3.2 & brown & $2 p$ \\
\hline
\end{tabular}

repeatable results. Therefore, only some of them are shown in Table 1. Mean diameters $\left(\mathrm{D}_{\mathrm{G}}\right)$ of individual granules varied from $1-4 \mathrm{~mm}$.

All granules sampled were cut into $100 \mu \mathrm{m}$ slices with a cryo-microtome (Leica CM 30505 Kryostat) and then analysed with a photon X analyser (Quantax Technology Silicon Drift) which was coupled with a scanning electron microscope.

The EDX probe was directed onto at least seven different locations in each granule section (see green marks in Figure 2) in order to ensure the repeatability of the results. The ash content of granules was measured according to standard methods. Samples were taken in triplicate for each site and were washed with distilled water to ensure that the supernatant did not interfere in the measurement.

\subsection{Characterization of liquid phases and calculation of saturation index}

The influent and effluent of each reactor were characterized according to standard methods [20]. The analytical results provided the input data for the geochemical software PHREEQC $^{\circledR}$ version 2.17, which was used to calculate the concentration of the chemical species in equilibrium for each liquid phase (acid, base, ion pairs). The SI for each mineral under study was calculated according to Equation (1), which considers the term $j$ (in contrast to the default calculation with PHREEQC ${ }^{\circledR}$ ) representing the number of ions contained in the mineral formula concerned [21,22].

$$
S I=\log \left(\frac{I A P}{K_{s p}}\right)^{1 / j}
$$

where $I A P$ is the ionic activity product of the ion activities involved in the mineral precipitation, and $K_{s p}$ refers to the thermodynamic mineral precipitation constant at a given temperature.

Deviation from the default database (Minteq v4) was proposed in order to include the thermodynamic data of some important minerals: struvite (MAP), amorphous calcium phosphate (ACP), hydroxydicalcium phosphate (HDP) and magnesium whitlockite (MWH) as shown in Table 2 [23-29].

\section{Results}

\subsection{Wastewater and process characteristics}

The influent and effluent of each reactor were analysed and characterized as described in section 2 , and the results are shown in Table 3 . The processes could be considered to have reached the steady state as they had been operating for more than 1 year before the sampling period. All the bioreactors showed high organic removal efficiency, as more than the $95 \%$ of the chemical oxygen demand (COD) was removed in these systems. Whey and dairy wastewaters are rich in phosphate and proteins, reflected by a high organic nitrogen content [30]. In anaerobic digesters, proteins are hydrolysed, explaining the decrease of COD and volatile suspended solids (VSS) and the increase of ammonium concentration in the effluents of each site.

In the aerobic reactors, organic compounds were oxidized to carbon dioxide, and ammonium was converted into nitrite and nitrates (nitrification), which were further converted into gaseous $\mathrm{N}_{2}$ (denitrification). Phosphates were partially removed by enhanced biological phosphorus removal (EBPR).

Alkalinity increased in the anaerobic reactors during methane production and in the aerobic reactors during the denitrification processes. This contributed to the $\mathrm{pH}$ rise, 
(a)

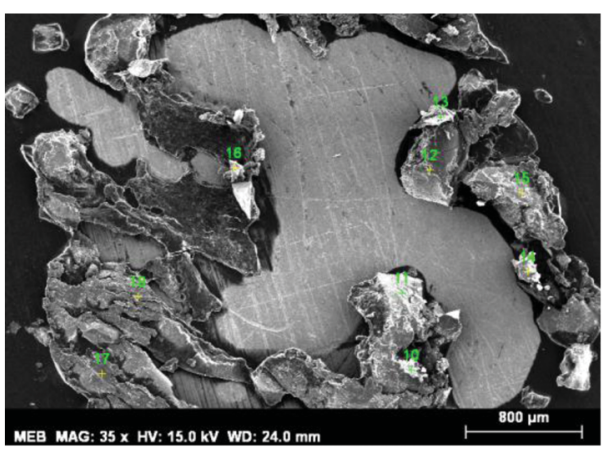

(c)

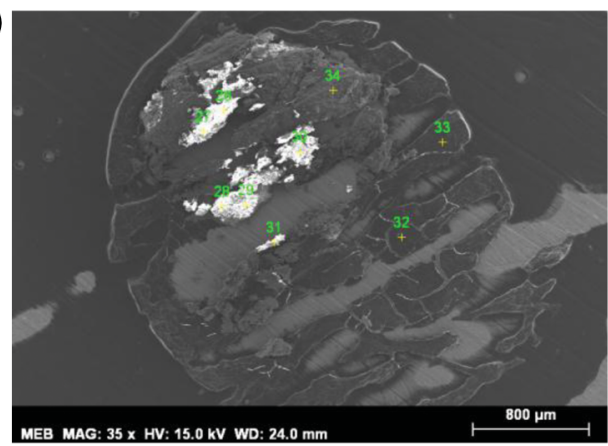

(e)

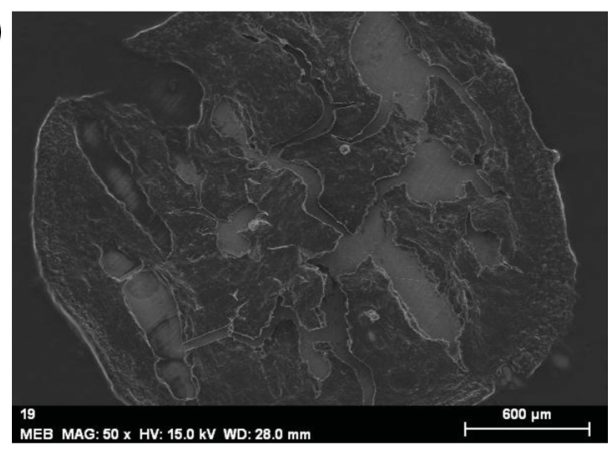

(g)

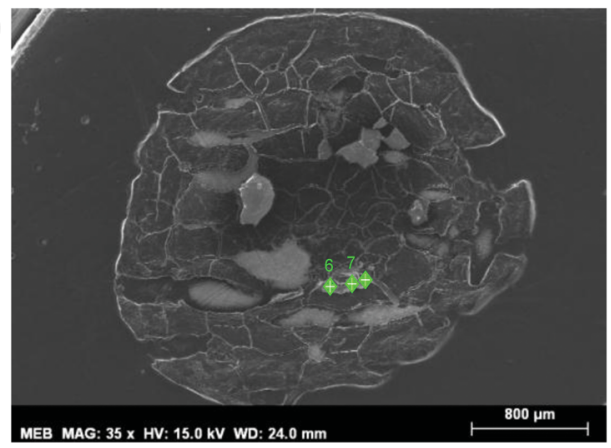

(b)

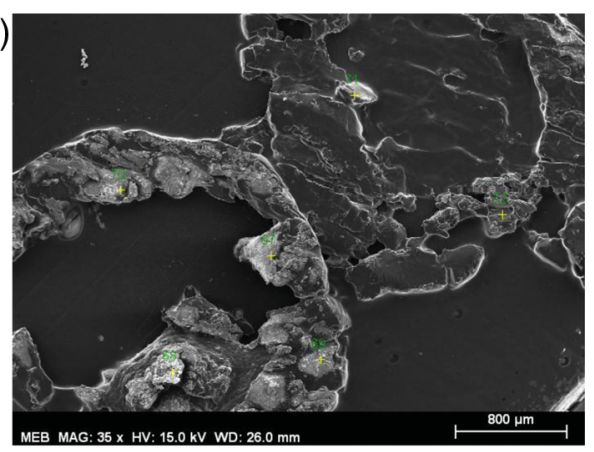

(d)

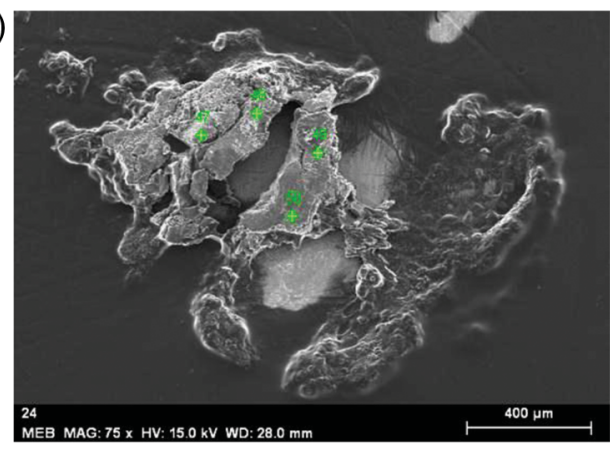

(f)

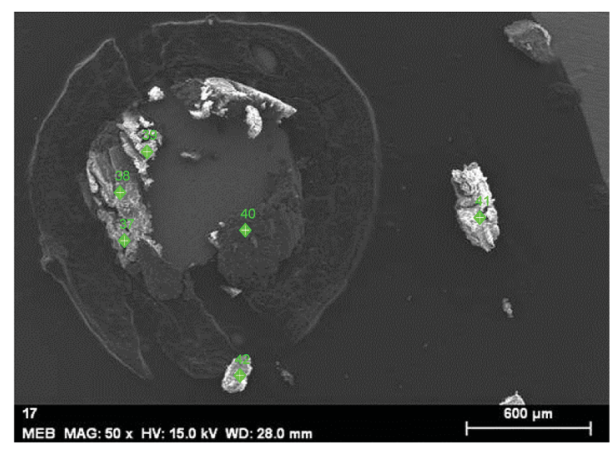

(h)

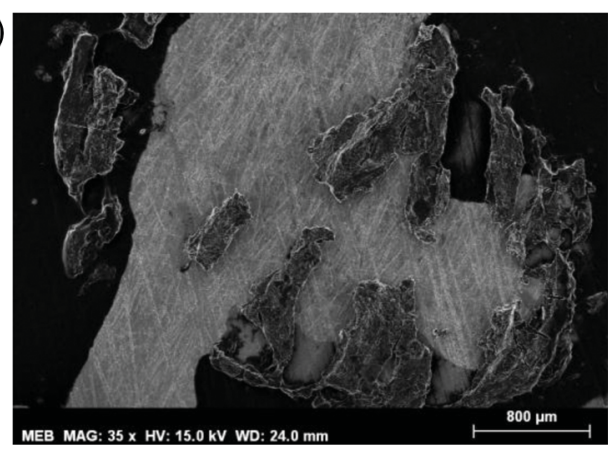

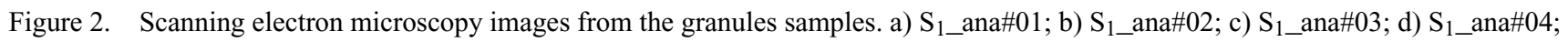

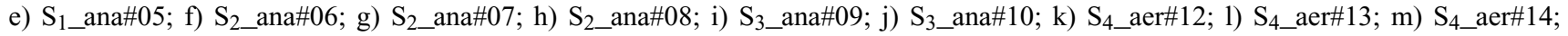
n) $S_{\left.5 \_a e r a \# 15 ; ~ o\right) ~} S_{5 \_}$aer\#16; p) $S_{2 \_}$aer\#17. Scale bar $=800 \mu \mathrm{m}$ for $(\mathrm{a}, \mathrm{b}, \mathrm{c}, \mathrm{f}, \mathrm{g}, \mathrm{i}, \mathrm{j}, \mathrm{k}, \mathrm{n}, \mathrm{o}, \mathrm{p}) ; 600 \mu \mathrm{m}$ for h, e, 1, m; $400 \mu \mathrm{m}$ for d.

which was also encouraged by stripping processes (carbon dioxide) in the aerobic reactors. Phosphate removal was observed in all the systems, probably due to precipitation processes in the anaerobic reactors, whereas both precipitation and biological phosphorus removal were shown to occur in the aerobic reactors [13].
For all sites, the mineral content of the suspended solids was higher in the effluent than in the influent and, simultaneously, calcium concentration in the liquid decreased in all the systems.

The high quantity of suspended solids in UASB processes was linked with the high mineral content 
(i)

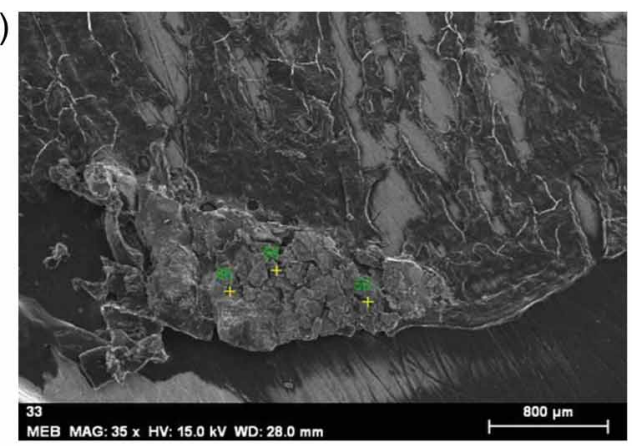

(k)

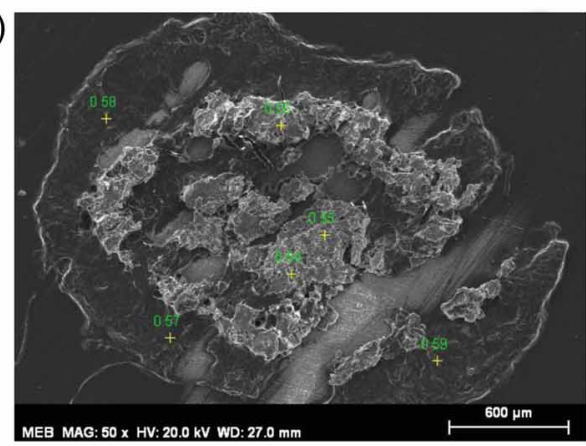

(m)

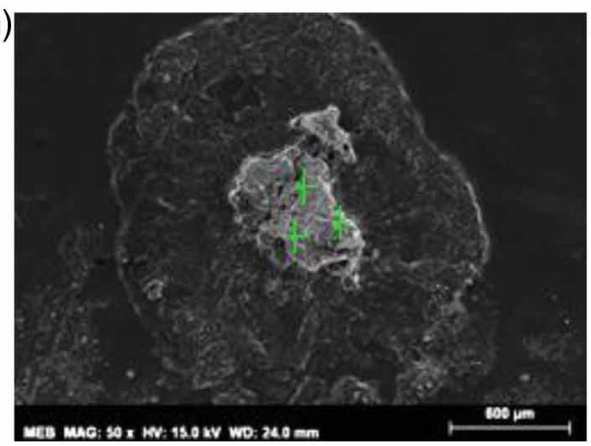

(o)

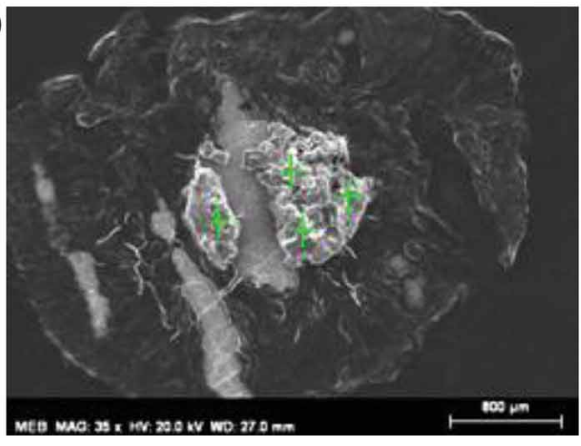

(j)

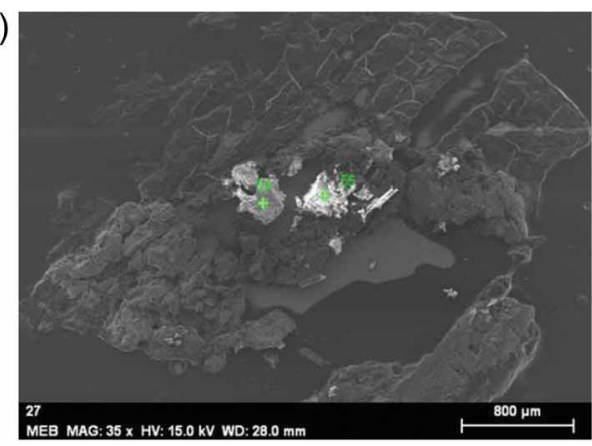

(l)

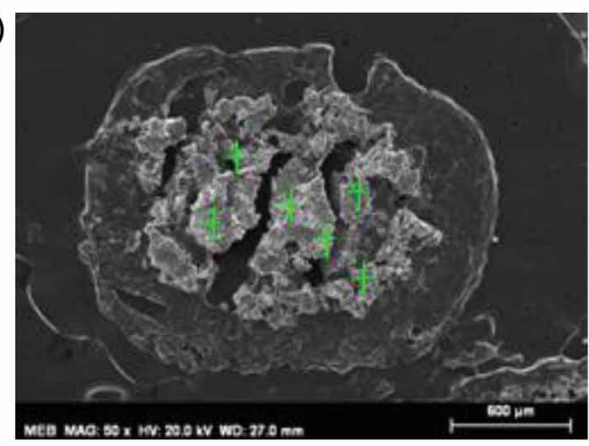

(n)

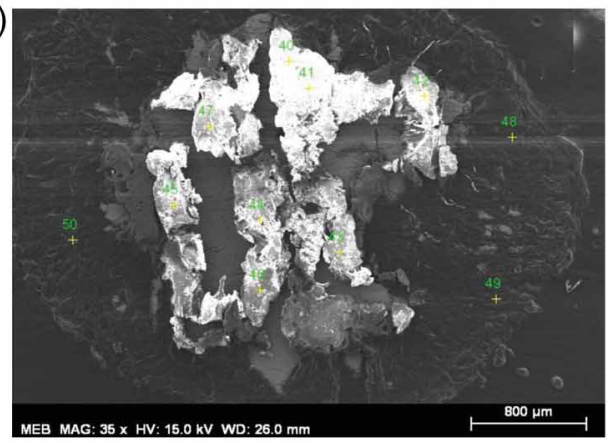

(p)

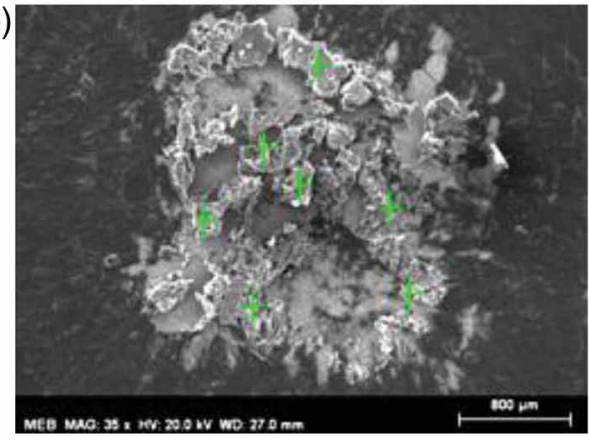

Figure 2. (continued)

(42.6-80\%). In these reactors, mineral content seemed to be correlated to $\mathrm{pH}$ : the highest $\mathrm{pH}$, for site 2, corresponded to the highest mineral content $(80 \%)$; the lowest $\mathrm{pH}$, for site 1 , corresponded to the lowest mixed liquor mineral content $(42.6 \%)$. Microscopic observations of the anaerobic effluent from site 2 showed that precipitated particles were visible in the reactor liquid phase (results not shown). In contrast, no minerals were found in the supernatant of the aerobic reactors. Finally, the ash content (sludge mineral fraction, SMF) of the different granules has been quantified in Table 3, indicating that, in aerobic systems, the quantity of minerals embedded in granules is strongly influenced by the process, as illustrated in GSBR 1 and GSBR 2: both reactors had similar mineral fractions in the mixed liquor $(33.7 \%$ and $38.7 \%$, respectively), but GSBR 2 had a higher (doubled) mineral content in the granules. At the same time, this 
Table 2. Thermodynamic constants of the main minerals considered for this study (modifications on the Minteq v4 database are indicated).

\begin{tabular}{|c|c|c|c|c|c|}
\hline Parameter & Chemical formula & Ksp value in modified database & $\mathrm{Ca} / \mathrm{P}$ & $\mathrm{Ca} / \mathrm{O}$ & $\mathrm{Mg} / \mathrm{P}$ \\
\hline CAL & $\mathrm{CaCO}_{3}$ & $6.35^{[23]}$ for Ic $>0.028 .48^{[23]}$ for Ic $<0.02$ & - & 0.33 & - \\
\hline ARAG & $\mathrm{CaCO}_{3}$ & $8.3^{[24]}$ & - & 0.33 & - \\
\hline DOL (ordered) & $\mathrm{CaMg}\left(\mathrm{CO}_{3}\right)_{2}$ & $17.09^{[* *]}$ & - & 0.17 & - \\
\hline MWH* & $\mathrm{Ca}_{18} \mathrm{Mg}_{2} \mathrm{H}_{2}\left(\mathrm{PO}_{4}\right)_{14}$ & $104.4^{[25]}$ & & & \\
\hline MAP* & $\mathrm{MgNH}_{4} \mathrm{PO}_{4}: 6 \mathrm{H}_{2} \mathrm{O}$ & $13.26^{[26]}$ & - & - & 1.00 \\
\hline NEW & $\mathrm{MgHPO}_{4}: 3 \mathrm{H}_{2} \mathrm{O}$ & $5.8^{[23,27]}$ & & & \\
\hline DCPD & $\mathrm{CaHPO}_{4}: 2 \mathrm{H}_{2} \mathrm{O}$ & $6.62^{[23]}$ & 1.00 & 0.25 & - \\
\hline DCPA & $\mathrm{CaHPO}_{4}$ & $6.9^{[28]}$ & 1.00 & 0.25 & - \\
\hline $\mathrm{OCP}$ & $\left.\mathrm{Ca}_{8}\left(\mathrm{HPO}_{4}\right)_{2}\left(\mathrm{PO}_{4}\right)_{4}\right): 5 \mathrm{H}_{2} \mathrm{O}$ & $49.6^{[28]}$ & 1.33 & 0.33 & - \\
\hline HDP* & $\mathrm{Ca}_{2} \mathrm{HPO}_{4}(\mathrm{OH})_{2}$ & $22.60^{[29]}$ & 2.00 & 0.33 & - \\
\hline $\mathrm{ACP} *$ & $\mathrm{Ca}_{3}\left(\mathrm{PO}_{4}\right)_{2}: \mathrm{xH}_{2} \mathrm{O}$ & $28.92^{[23]}$ & 1.50 & 0.38 & - \\
\hline TCP & $\mathrm{Ca}_{3}\left(\mathrm{PO}_{4}\right)_{2}$ & $32.63^{[27]}$ & 1.50 & 0.38 & - \\
\hline HAP & $\mathrm{Ca}_{5}\left(\mathrm{PO}_{4}\right)_{3}(\mathrm{OH})$ & $58.33^{[23,26]}$ & 1.67 & 0.38 & - \\
\hline
\end{tabular}

reactor was the one in which the EBPR process was most remarkable [31]. In anaerobic sites, the sludge ash content was also different, varying from $28-81 \%$. In UASB where SMF achieved the highest values (sites 1 and 2), removal efficiency problems were reported and the reactors needed to be re-seeded.

\subsection{Analysis of mineral bioliths in granules}

Figure 2 shows the SEM images taken from the different sectioned granule samples. SEM and EDX probes testing at different locations on the samples confirmed that almost all of the granules (except two: the black ones) presented inorganic mineral concretions. These precipitates were easily detectable due to their geometrical shape, brightness and low organic matter content. In the photographs, crystallized minerals appear lighter than the organic fraction. They were mainly observed inside the granules but, in some cases, precipitates were formed at the surface, as in Figure $2 \mathrm{a}$ and $2 \mathrm{~b}$, in which a mineral layer envelops the anaerobic microbial granule. Finally, samples shown in Figure $2 \mathrm{e}$ and $2 \mathrm{~h}$ did not present any sign of mineral deposition either embedded in, or surrounding, the bio-aggregate.

Bioliths found in the anaerobic granules were randomly distributed (Figure 2c, 2d, 2f, 2g, 2i and 2j), although they formed a biofilm of at least $400 \mu \mathrm{m}$ beyond the aggregate surface. The bioliths in aerobic granules (Figure $2 \mathrm{k}-2 \mathrm{p}$ ) constituted a large solid fraction centred on the core, at least $300 \mu \mathrm{m}$ from the surface layer for Figure $2 \mathrm{k}$ and 21, and $800 \mu \mathrm{m}$ for Figure $2 \mathrm{~m}-2 \mathrm{p}$.

In the case of the granules in Figure $2 \mathrm{a}$ and $2 \mathrm{~b}$, the mineral shell that covered the aggregates was around 400 $800 \mu \mathrm{m}$ thick on average, which represented a considerable fraction of the minerals present, probably affecting the diffusion of nutrients and bacterial activity.

Analyses were carried out with EDX probes directed at the mineral clusters (marked with small crosses), revealing the major element composition and indicating the nature of the mineral formed (Table 4). A number of local analyses (at least seven) were carried out for each granule at different locations in the mineral clusters. Average values and standard deviations are shown in Table 4.

It was clear that, after oxygen, calcium was the major constituent of the mineral fraction, varying from $22-49 \%$ for anaerobic granules and from $17-38 \%$ for aerobic granules. The other major constituent was phosphorus, except for the granules collected in UASB reactor 2. Phosphorus content varied from $0.06-24 \%$ and from $7-15 \%$ for anaerobic and aerobic granules, respectively. The magnesium content of the clusters was smaller $(<1 \%)$ and nitrogen was sparsely found in variable concentrations $(0-4 \%)$ in some granules.

The data indicate that the molar $\mathrm{Ca}: \mathrm{P}$ ratio varied from 1.25-1.68 in the different granules (except for those from site 2 , in which no significant amounts of phosphorus were found). These values are evocative of several calcium phosphates with varying theoretical $\mathrm{Ca}: \mathrm{P}$ ratios: octacalcium phosphate $\left.\left[\mathrm{Ca}_{8}\left(\mathrm{HPO}_{4}\right)_{2}\left(\mathrm{PO}_{4}\right)_{4}\right): 5 \mathrm{H}_{2} \mathrm{O}\right](\mathrm{OCP})(1.33)$; amorphous calcium phosphate $\left[\mathrm{Ca}_{3}\left(\mathrm{PO}_{4}\right)_{2}: \mathrm{xH}_{2} \mathrm{O}\right](\mathrm{ACP})$ (1.5); tricalcium phosphate $\left[\mathrm{Ca}_{3}\left(\mathrm{PO}_{4}\right)_{2}\right]$ (TCP) (1.5); and hydroxyapatite $\left[\mathrm{Ca}_{5}(\mathrm{OH})\left(\mathrm{PO}_{4}\right)_{3}(\mathrm{OH})\right]$ (HAP) (1.67). For some samples, $\mathrm{Ca}: \mathrm{O}$ ratios were also of the same order of magnitude as theoretical values of calcium phosphate or calcium carbonate ( $0.33-0.38$, see Table 2$)$, but the $\mathrm{Ca}$ : $\mathrm{O}$ ratio showed much greater variation than that of $\mathrm{Ca}: \mathrm{P}$, making its interpretation more difficult.

The solid phase most probably formed in the granules, according to their $\mathrm{Ca}: \mathrm{P}$ and $\mathrm{Ca}: \mathrm{O}$ molar ratios, are suggested in the last column of Table 4. Calcium phosphates ACP, TCP, HAP were the most probable solids in the granules, except for those from UASB 2, which seemed to contain calcium carbonate (Aragonite $\left[\mathrm{CaCO}_{3}\right]$ (ARAG) or calcium carbonate, calcite $\left.\left[\mathrm{CaCO}_{3}\right](\mathrm{CAL})\right)$. Almost all the aerobic granules had $\mathrm{Ca}: \mathrm{P}$ ratios close to that of HAP, except for one sample from GSBR-2, in which the $\mathrm{Ca} P \mathrm{P}$ ratio was closer to ACP (or TCP). As ACP and TCP are both possible precursors of HAP, further work [32] revealed that ACP was the hydroxyapatite precursor in aerobic granules. 
Table 3. Characterization of the influent and effluent streams of each bioreactor.

\begin{tabular}{|c|c|c|c|c|c|c|c|c|c|c|c|c|}
\hline & & & \multicolumn{2}{|c|}{$\begin{array}{c}\text { Site } 1 \\
\text { UASB } \\
\text { anaerobic }\end{array}$} & \multicolumn{2}{|c|}{$\begin{array}{c}\text { Site } 2 \\
\text { UASB } \\
\text { anaerobic }\end{array}$} & \multicolumn{2}{|c|}{$\begin{array}{c}\text { Site } 3 \\
\text { UASB } \\
\text { anaerobic }\end{array}$} & \multicolumn{2}{|c|}{$\begin{array}{c}\text { Site } 4 \\
\text { GSBR-1 } \\
\text { anoxic/aerobic }\end{array}$} & \multicolumn{2}{|c|}{$\begin{array}{c}\text { Site } 5 \\
\text { GSBR-2 } \\
\text { anaerobic/aerobic }\end{array}$} \\
\hline & & & Influent & Effluent & Influent & Effluent & Influent & Effluent & Influent & Effluent & Influent & Effluent \\
\hline \multirow{17}{*}{$\begin{array}{l}\text { Liquid } \\
\text { phase }\end{array}$} & $\mathrm{Cl}^{-}$ & $\mathrm{mg} / \mathrm{L}$ & 652 & 658 & 754 & 641 & 464 & 451 & 181 & 164 & 175 & 170 \\
\hline & $\mathrm{N}-\mathrm{NO}_{2}^{-}$ & $\mathrm{mg} / \mathrm{L}$ & 1.10 & - & 1.20 & - & 0.21 & 0.29 & - & 0.095 & 0 & 0.08 \\
\hline & $\mathrm{N}-\mathrm{NO}_{3}^{-}$ & $\mathrm{mg} / \mathrm{L}$ & 4.60 & 3.30 & 6.20 & 2.35 & 6.41 & 1.08 & 111 & 16.14 & 1.13 & 0.25 \\
\hline & $\mathrm{P}-\mathrm{PO}_{4}^{3-}$ & $\mathrm{mg} / \mathrm{L}$ & 191 & 118 & 121 & 114 & 107 & 73.0 & 31.2 & 17.04 & 31.25 & 15.9 \\
\hline & $\mathrm{Na}^{+}$ & $\mathrm{mg} / \mathrm{L}$ & 145 & 515 & 304 & 410 & 302 & 710 & 391 & 348 & 209 & 208 \\
\hline & $\mathrm{N}-\mathrm{NH}_{4}^{+}$ & $\mathrm{mg} / \mathrm{L}$ & 122 & 323 & 71.7 & 315 & 0.86 & 320 & 64.6 & 0 & 59.08 & 9.93 \\
\hline & $\mathrm{K}^{+}$ & $\mathrm{mg} / \mathrm{L}$ & 167 & 442 & 441 & 415 & 418 & 512 & 45.1 & 33.9 & 45.2 & 35.1 \\
\hline & $\mathrm{Mg}^{2+}$ & $\mathrm{mg} / \mathrm{L}$ & 15.55 & 32.53 & 22.7 & 21.95 & 19.39 & 11.04 & 4.39 & 3.63 & 4.19 & 2.98 \\
\hline & $\mathrm{Ca}^{2+}$ & $\mathrm{mg} / \mathrm{L}$ & 80.9 & 76.5 & 132 & 90.9 & 150 & 88.7 & 46.0 & 29.1 & 43.6 & 24.3 \\
\hline & TKN & $\mathrm{mg} / \mathrm{L}$ & 831 & 968 & 558 & 422 & nd & nd & 64.6 & nd & 59.1 & nd \\
\hline & COD & $\mathrm{mg} / \mathrm{L}$ & 29120 & 240 & 16380 & 120 & 23760 & 2705 & 1000 & 45 & 1000 & 75 \\
\hline & TIC & $\mathrm{mg} / \mathrm{L}$ & - & 363 & - & 919 & - & nd & 23.3 & - & 24.00 & 50.7 \\
\hline & $\mathrm{pH}$ & - & 3.62 & 6.67 & 3.54 & 7.4 & 3.61 & 6.88 & 7.54 & 8.22 & 7.6 & 7.9 \\
\hline & $\mathrm{T}$ & ${ }^{\circ}(\mathrm{C})$ & 15 & 33 & 15 & 30 & 15 & 29 & 12 & 21 & 12 & 21 \\
\hline & $\mathrm{Ca} / \mathrm{P}$ & $\mathrm{mol} / \mathrm{mol}$ & 0.33 & 0.50 & 0.85 & 0.62 & 1.08 & 0.94 & 1.14 & 1.32 & 1.08 & 1.18 \\
\hline & $\mathrm{Ca} / \mathrm{Na}$ & $\mathrm{mol} / \mathrm{mol}$ & 0.56 & 0.15 & 0.43 & 0.22 & 0.50 & 0.12 & 0.12 & 0.08 & 0.21 & 0.12 \\
\hline & $\mathrm{Ca} / \mathrm{Mg}$ & $\mathrm{mol} / \mathrm{mol}$ & 3.16 & 1.43 & 3.53 & 2.51 & 4.71 & 4.87 & 6.35 & 4.85 & 6.31 & 4.94 \\
\hline Suspended & SS & $\mathrm{g} / \mathrm{L}$ & 20.8 & 5.59 & 18.28 & 3.15 & 12.86 & 5.42 & - & 0.3 & - & 0.4 \\
\hline solids & VSS & $\mathrm{g} / \mathrm{L}$ & 17.64 & 3.21 & 15.98 & 0.63 & 10.07 & 2.12 & - & 0.1 & - & 0.2 \\
\hline & MF & $\%$ (mass) & 15.19 & 42.58 & 12.58 & 80.00 & 21.70 & 60.89 & - & 33.65 & - & 38.70 \\
\hline Granular sludge & SMF Ash content & $\%$ of dry mass & \multicolumn{2}{|c|}{$81.0 \pm 0.4$} & \multicolumn{2}{|c|}{$71.7 \pm 1.2$} & \multicolumn{2}{|c|}{$28.2 \pm 0.5$} & \multicolumn{2}{|c|}{$33.5 \pm 0.4$} & \multicolumn{2}{|c|}{$68.4 \pm 2.2$} \\
\hline
\end{tabular}


Table 4. EDX analysis of mineral clusters found in anaerobic and aerobic granules (average values from at least seven analyses for each granule): elemental composition (percentage in mass), molar ratios, most probable solid phase.

\begin{tabular}{|c|c|c|c|c|c|c|c|c|}
\hline Sample & $\% \mathrm{Ca}$ & $\% \mathrm{P}$ & $\% \mathrm{Mg}$ & $\% \mathrm{~N}$ & $\% \mathrm{O}$ & $\begin{array}{c}\mathrm{Ca} / \mathrm{P} \\
\text { (molar) }\end{array}$ & $\begin{array}{c}\mathrm{Ca} / \mathrm{O} \\
\text { (molar) }\end{array}$ & $\begin{array}{c}\text { Mineral } \\
\text { (probable) }\end{array}$ \\
\hline $\mathrm{S} 1$ _ana\#1 & $27.77 \pm 5.70$ & $11.62 \pm 2.53$ & $0.35 \pm 0.19$ & $1.71 \pm 1.46$ & $44.33 \pm 6.22$ & $1.40 \pm 0.05$ & $2.86 \pm 0.30$ & $\mathrm{ACP} / \mathrm{TCP}$ \\
\hline $\mathrm{S} 1$ _ana\#2 & $31.91 \pm 7.21$ & $13.37 \pm 2.42$ & $0.51 \pm 0.15$ & $2.86 \pm 3.55$ & $39.29 \pm 4.14$ & $1.47 \pm 0.01$ & $0.52 \pm 0.11$ & $\mathrm{ACP} / \mathrm{TCP}$ \\
\hline $\mathrm{S} 1$ _ana\#3 & $46.92 \pm 17.36$ & $0.17 \pm 0.16$ & $0.02 \pm 0.06$ & $0.51 \pm 0.60$ & $48.81 \pm 4.66$ & - & $0.99 \pm 0.28$ & CAL/ARAG \\
\hline $\mathrm{S} 1$ _ana\#4 & $48.99 \pm 5.93$ & $24.02 \pm 1.65$ & - & - & $33.36 \pm 16.81$ & $1.25 \pm 0.12$ & $0.68 \pm 0.25$ & OCP \\
\hline $\mathrm{S} 1$ _ana\#5 & - & - & - & - & - & - & - & - \\
\hline $\mathrm{S} 2$ _ana\#6 & $31.25 \pm 8.57$ & $0.06 \pm 0.14$ & $0.06 \pm 0.10$ & - & $49.59 \pm 3.38$ & - & $0.26 \pm 0.03$ & CAL/ARAG \\
\hline $\mathrm{S} 2$ _ana\#7 & $29.43 \pm 7.11$ & $0.26 \pm 0.18$ & $0.24 \pm 0.17$ & $2.06 \pm 1.80$ & $47.65 \pm 1.88$ & $110 \pm 59$ & $0.28 \pm 0.12$ & CAL/ARAG \\
\hline S2_ana\#8 & - & - & - & - & - & - & - & - \\
\hline $\mathrm{S} 3$ _ana\#10 & $26.28 \pm 4.29$ & $11.10 \pm 2.29$ & $0.19 \pm 0.14$ & - & $31.64 \pm 4.27$ & $1.44 \pm 0.08$ & $0.33 \pm 0.01$ & $\mathrm{ACP} / \mathrm{TCP}$ \\
\hline S3_ana\#11 & $22.40 \pm 8.90$ & $9.36 \pm 2.99$ & $0.39 \pm 0.05$ & - & $42.89 \pm 0.00$ & $1.42 \pm 0.12$ & $0.21 \pm 0.08$ & $\mathrm{ACP} / \mathrm{TCP}$ \\
\hline S4_aer\#12 & $32.18 \pm 8.68$ & $13.42 \pm 2.61$ & $0.34 \pm 0.16$ & - & $40.55 \pm 0.15$ & $1.65 \pm 0.10$ & $0.38 \pm 0.18$ & HAP \\
\hline S4_aer\#13 & $32.55 \pm 4.98$ & $12.37 \pm 1.94$ & $0.24 \pm 0.28$ & - & $41.07 \pm 0.89$ & $1.68 \pm 0.04$ & $0.39 \pm 0.21$ & HAP \\
\hline S4_aer\#14 & $38.17 \pm 11.61$ & $14.45 \pm 3.07$ & $0.67 \pm 0.19$ & - & $46.05 \pm 14.32$ & $1.62 \pm 0.05$ & $0.64 \pm 0.20$ & HAP \\
\hline S5_aer\#15 & $25.80 \pm 3.07$ & $11.38 \pm 1.01$ & $0.43 \pm 0.13$ & - & $46.65 \pm 3.46$ & $1.64 \pm 0.04$ & $0.31 \pm 0.07$ & HAP \\
\hline S5_aer\#16 & $16.46 \pm 1.58$ & $7.19 \pm 0.49$ & $0.31 \pm 1.20$ & $4.26 \pm 1.51$ & $39.9 \pm 0.07$ & $1.53 \pm 0.07$ & $0.17 \pm 0.02$ & $\mathrm{ACP} / \mathrm{TCP}$ \\
\hline S5_aer\#17 & $32.73 \pm 5.07$ & $11.96 \pm 1.64$ & $0.10 \pm 0.09$ & $0.42 \pm 0.55$ & $34.43 \pm 5.86$ & $1.60 \pm 0.04$ & $0.31 \pm 0.07$ & HAP \\
\hline
\end{tabular}

-: mineral not found or element not detectable 
At the anaerobic sites, results showed heterogeneity in the chemical composition of the different granules sampled for each site. Granules from anaerobic sites were different in colour and size (see Table 1), and the nature of minerals found inside aggregates were also different in a given reactor. For instance, at site 1 we found different granules containing calcium carbonate and calcium phosphates. At site 2, all granules containing mineral bioliths appeared to be made up of calcite or aragonite. Anaerobic granules from site 3 all contained calcium phosphates, probably ACP or TCP.

\subsection{Calcium phosphate distribution during granule growth: the case of GSBR}

By focusing on the granular sludge from aerobic systems (GSBR), it was observed that small granules were continuously generated in the reactor and grew progressively with microbial activity (this process is much slower in the case of anaerobic methanogenic bacteria, whose growth rate is more than 10 times lower than those of aerobic bacteria). Therefore, different aerobic granules with different sizes were sampled from two GSBR reactors $(\mathrm{R} 1=$ site 4 , and $\mathrm{R} 2=$ site 5$)$, assuming that the biggest granules would be more mature than the small ones. Only the central sections are shown in Figure 3, illustrating the evolution of the mineral formation inside the microbial aggregates from small granules to mature ones.

It can be noted that the solid mineral precipitated in the centre of the small granules and increased progressively, at the same time as microbial biofilm developed at the surface of the granule. In the biggest granules, successive rings of mineral were finally visible, indicating past growing periods (reminiscent of the rings of a tree trunk). Different mature granules from both reactors presenting a mineral ring-distribution were analysed with an EDX probe, as shown in Figure 4.

A detailed analysis with EDX probes was performed in two different zones of the mineral core of the granules:
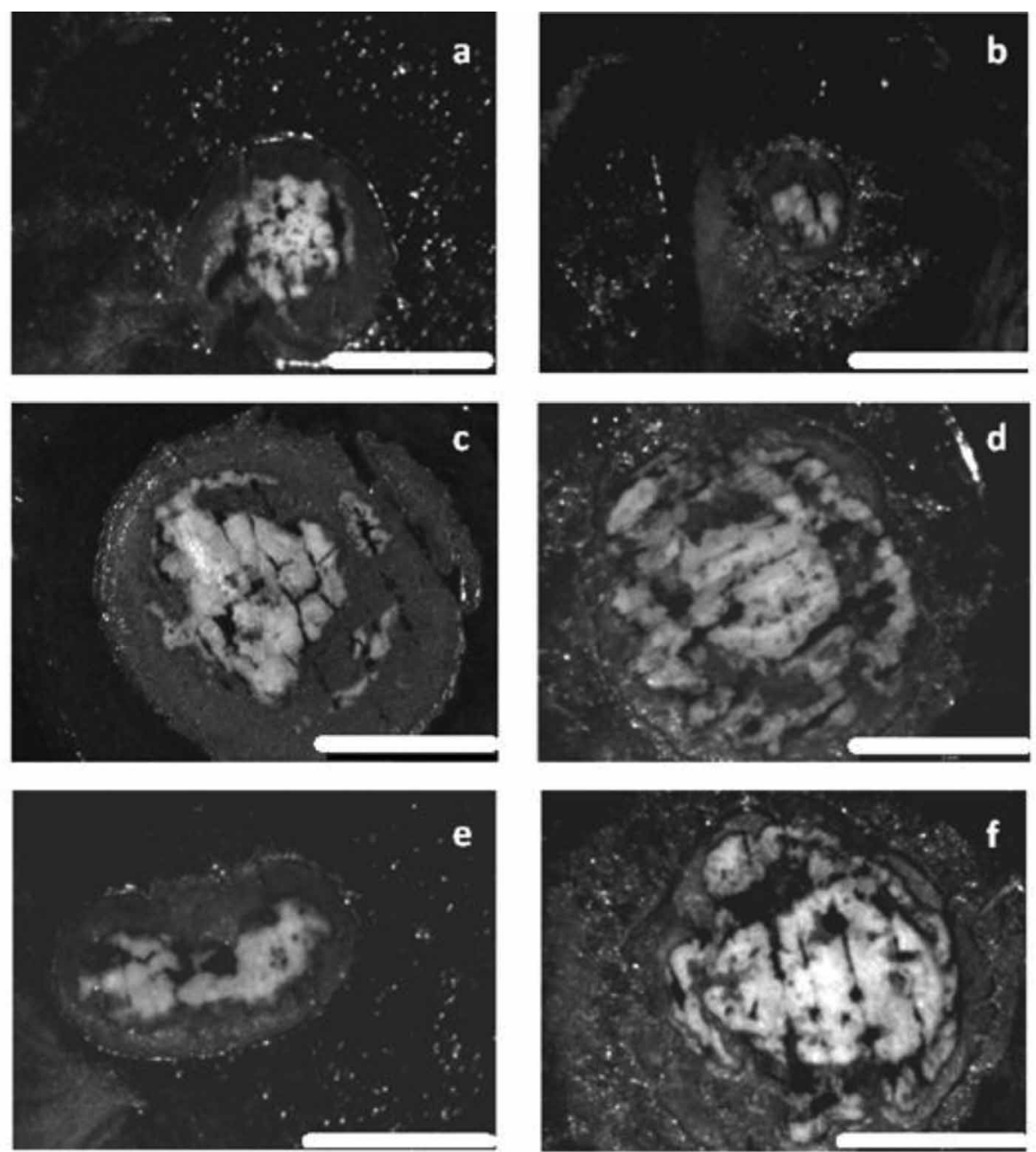

Figure 3. Binocular images of central slices from different granules of GSBR, classified from smallest to largest; a) S4_aer\#18; b) S5_aer\#19; c) S4_aer\#20; d) S5_aer\#21; e) S4_aer\#22; f) S5_aer\#23. Scale bar is $2 \mathrm{~mm}$ length. 

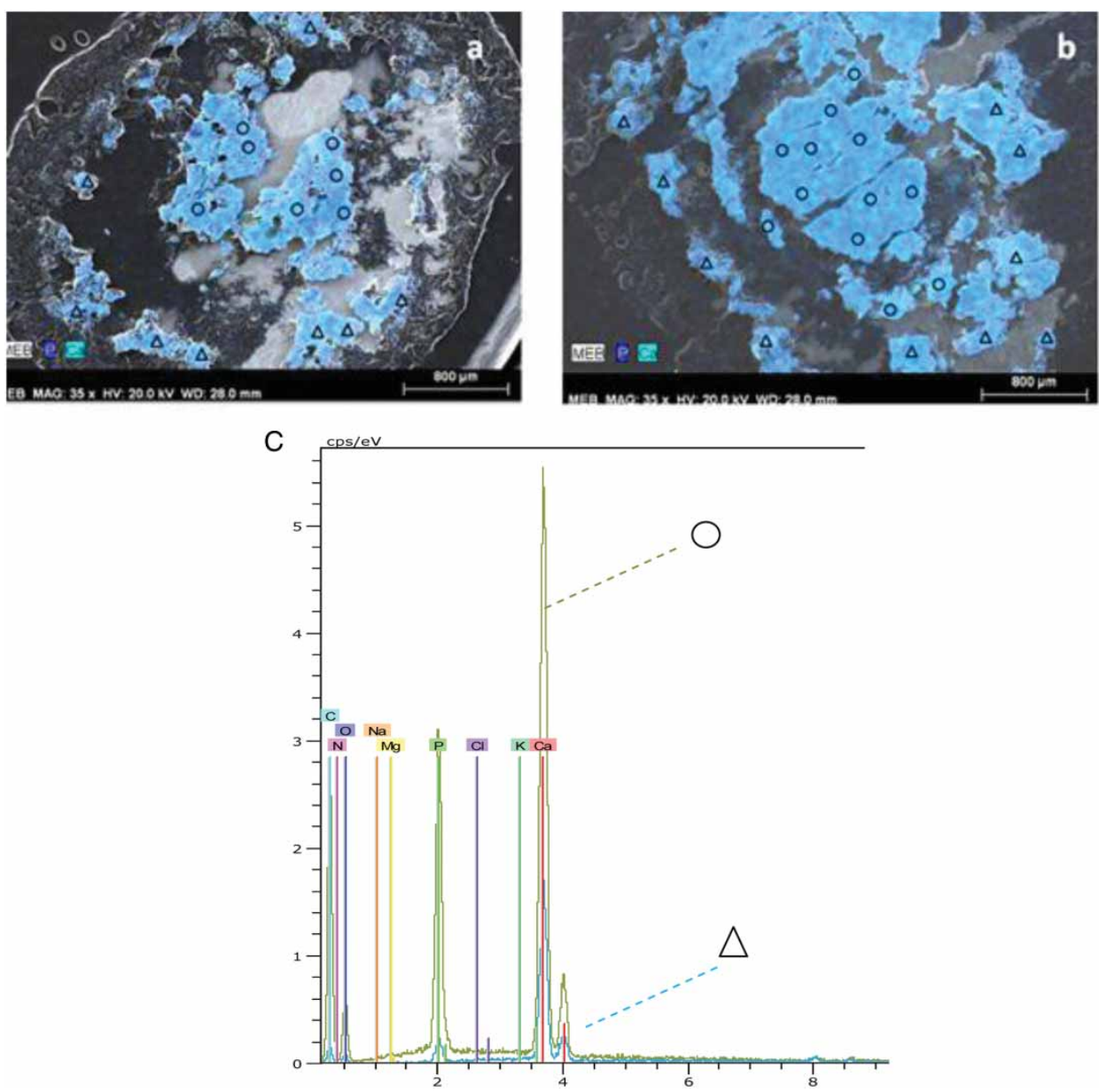

Figure 4. EDX analysis of the mineral layers in granules from GSBR. a) granule from R1; b) granule from R2; c) Inner ( ) and outer ( ) layer-patterns with EDX analysis from Figure $4 \mathrm{a}$.

in the central zone and in the external rings, as indicated in Figure 4. The results show that mineral precipitates had slightly different compositions in the inner part compared with the external layer. In the granule shown in Figure 4a, the mean value of $\mathrm{Ca}: \mathrm{P}$ ratio of the internal layer was close to that of HAP $(1.69 \pm 0.19)$ whereas the mineral in the outer layer showed a lower mean Ca:P ratio of $1.52 \pm 0.20$, close to that of the precursor ACP (theoretical $\mathrm{Ca}: \mathrm{P}=1.5$ ). In the second example, shown in Figure $4 \mathrm{~b}$, there are three concentric layers. A lower $\mathrm{Ca}: \mathrm{P}$ ratio was found in the outer layer of mineral $(1.29 \pm 0.05)$ whereas the inner part had a $\mathrm{Ca}: \mathrm{P}$ molar ratio of $1.50 \pm 0.16$.

These results indicate a possible conversion from calcium phosphate precursors with lower Ca:P ratio (ACP, TCP or OCP) to the more stable calcium phosphate hydroxyapatite (HAP), with the highest ratio found in the centre (theoretical Ca:P ratio $=1.67$ ). These results are consistent with the traditional idea that HAP formation is not the result of spontaneous nucleation but of a progressive conversion of less-stable calcium phosphates, indicating that a minimal retention time in the granule is necessary to convert the precursor phases (probably ACP, TCP, or OCP) into HAP.

\subsection{Calculation of saturation index in the different reactors}

The SI of the minerals that could precipitate were calculated with PHREEQC software according to the liquid composition of each reactor stream. The $\mathrm{pH}$ and temperature values used in the calculations were those of the reactor outputs. It was assumed that the conditions inside each reactor were similar to those of the outlet if proper mixing was imposed in the reactor, which, considering the different scale, is more realistic in the case of laboratoryscale reactors (sites 4 and 5) than in the full-scale UASB reactors (sites 1, 2 and 3).

The results (shown in Table 5) indicate the compounds with a positive SI, which were likely to precipitate. Concerning calcium phosphate, results confirmed that HAP, ACP, TCP and ordered dolomite (DOL) were systematically supersaturated in all the samples, which is in accordance with the analysis of the solid phase.

Calculations also showed that MAP was under-saturated in all the reactors, as were newberite $\left[\mathrm{MgHPO}_{4}: 3 \mathrm{H}_{2} \mathrm{O}\right]$ (NEW), MWH and OCP. Finally, brushite $\left[\mathrm{CaHPO}_{4}\right.$ : $\left.2 \mathrm{H}_{2} \mathrm{O}\right]($ DCPD) and phosphate dicalcic anhydrous, monetite 
Table 5. SI values for the mineral phases calculated with PHREEQC in the effluent.

\begin{tabular}{|c|c|c|c|c|c|}
\hline Mineral phase & UASB_site 1 & UASB_site 2 & UASB_site 3 & GSBR_site 4 & GSBR_site 5 \\
\hline ARAG & -0.09 & 0.44 & 0.18 & 0.23 & 0.20 \\
\hline CAL & -1.08 & -0.55 & -0.81 & 0.33 & 0.29 \\
\hline DOL(ord) & 0.02 & 0.49 & 0.15 & 0.18 & 0.14 \\
\hline MWH & -2.72 & -2.50 & -2.78 & -2.45 & -2.48 \\
\hline MAP & -0.27 & -0.10 & -0.45 & - & -0.61 \\
\hline NEW & -0.37 & -0.46 & -0.73 & -0.94 & -0.98 \\
\hline DCPD & 0.06 & 0.09 & -0.04 & -0.18 & -0.20 \\
\hline DCPA & 0.18 & 0.22 & 0.10 & -0.03 & -0.05 \\
\hline $\mathrm{OCP}$ & -5.63 & -5.27 & -5.71 & -5.27 & -5.33 \\
\hline HDP & -0.24 & 0.00 & -0.26 & 0.15 & 0.13 \\
\hline $\mathrm{ACP}$ & 0.25 & 0.55 & 0.26 & 0.73 & 0.70 \\
\hline TCP & 1.04 & 1.32 & 1.02 & 1.45 & 1.41 \\
\hline HAP & 0.92 & 1.23 & 0.92 & 1.44 & 1.41 \\
\hline Ic & 0.05 & 0.10 & 0.08 & 0.02 & 0.01 \\
\hline $\mathrm{pH}$ & 6.67 & 7.4 & 6.88 & 8.41 & 7.85 \\
\hline $\mathrm{T}\left({ }^{\circ} \mathrm{C}\right)$ & 33 & 30 & 29 & 21 & 21 \\
\hline
\end{tabular}
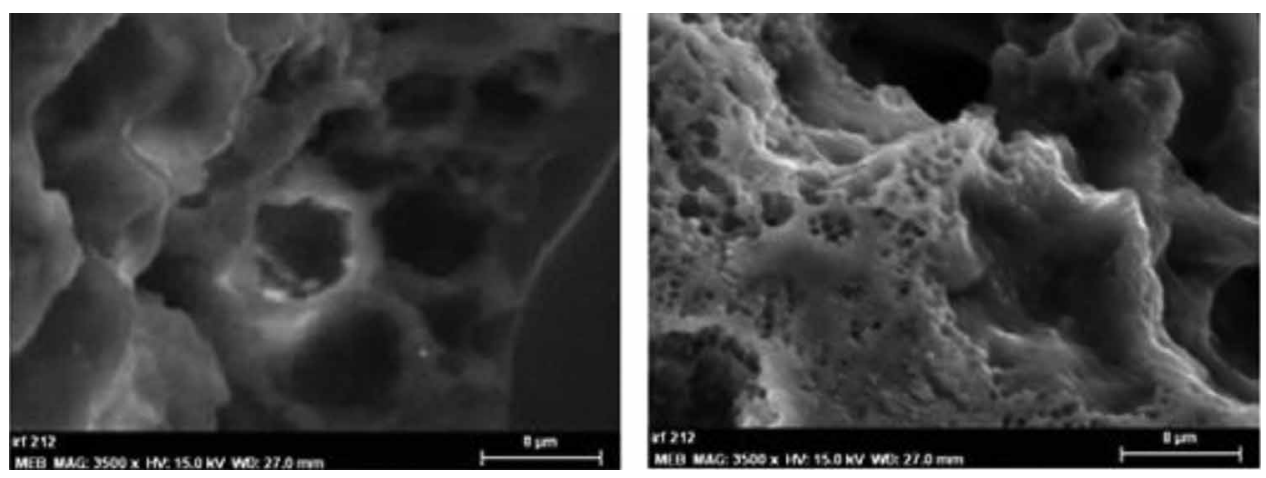

Figure 5. Scanning electron microscopy images of aerobic granules. Scale bar $=8 \mu \mathrm{m}$.

[CaHPO 4 (DCPA), both precursors of HAP, were found to be supersaturated in some anaerobic reactors but not in aerobic ones (GSBRs). Calcium carbonates, be they calcite (CAL) or aragonite (ARAG), were supersaturated in most of the systems, except for UASB 1. The highest SI value achieved was at site 2 , where calcium carbonates had been detected in the solid phase. Crystals were never observed in the supernatant of the aerobic granular sludge process, in contrast to anaerobic sites where solid crystals were detected in some samples from site 2 (results not shown here).

Carbonate saturation is encouraged by the accumulation of mineral carbon produced by microbial reactions. Higher SI values were observed for anaerobic site 2, at which the $\mathrm{pH}$ (7.4) was slightly higher than in other anaerobic processes (sites 1 and 3). In aerobic systems, because aeration encouraged carbon dioxide stripping and nitrification consumed alkalinity, inorganic carbon concentration was lower than in anaerobic reactors. However, the relatively high $\mathrm{pH}$ at which both GSBRs worked explained the super-saturation of calcium carbonate at sites 4 and 5 .

The SI values in the effluent indicate the mineral that is still supersaturated after the process. However, due to a long retention time and possible rapid precipitation (especially in anaerobic systems), equilibrium can be reached in the reactors, leading to a reduction of SI (stabilized around zero). Thus, the variation of SI (namely $\Delta$ SI) was calculated between the SI calculated for outlet concentrations and the SI calculated for the inlet concentrations of the volume control (each reactor).

$$
\Delta \mathrm{SI}=\mathrm{SI}_{\text {effluent }}-\mathrm{SI}_{\text {influent }}
$$

Of all the minerals included in the simulation, only those with positive SI in least one stream were considered for the $\Delta$ SI calculation in Figure 5. Thus, a $\Delta \mathrm{SI}<0$ could indicate a possible SI decrease in the effluent due to precipitation. Although alkalinity was produced during the anaerobic processes, a decrease of SI was observed in UASB 2, which indicated that calcium carbonate should precipitate, in accordance with previous local observations.

\section{Discussion}

\subsection{Nature of precipitates: consistency between the local observations and the $S I$}

SEM-EDX analysis demonstrated that calcium phosphates were the major precipitates found in the granules, both 
aerobic and anaerobic. More specifically, solid composition was close to those of HAP, ACP or TCP. This was consistent with the analyses of SI in the liquid phase, indicating that these minerals were systematically saturated.

Concerning other calcium phosphate precursors, only one sample (brown-type, $\mathrm{S}_{1 \_ \text {ana }} 4$ ) showed $\mathrm{Ca}: \mathrm{P}$ and $\mathrm{Ca}: \mathrm{O}$ ratios that could implicate an OCP precursor. This seems consistent with the fact that $\mathrm{pH}$ was the lowest at site 1 , and Gao and co-workers [33] have reported the formation of HAP through OCP precursor at acidic $\mathrm{pH}$. However, of all the calcium phosphate precursors proposed in the literature for acidic $\mathrm{pH}$ (DCPD, DCPA and OCP), only OCP was not observed to be saturated in the liquid phase according to PHREEQC calculations.

Calcium carbonates were only observed in some granules, mainly at site 2 , coinciding with the highest $\mathrm{pH}$ and alkalinity values among the anaerobic sites. In the aerobic reactors, despite $\mathrm{pH}$ values higher than in the anaerobic ones, alkalinity was reduced by the nitrification reactions, explaining the lower carbonate precipitation potential. Carbonates are well-known competitors with phosphates for calcium binding, competing for the active nucleation and crystal growth sites [17,34]. Moreover, it is known that this competition is severely influenced by $\mathrm{pH}$ [35]. Working with digester supernatant, Battistoni et al. [36] reported that a $\mathrm{pH}$ between 7.0 and 8.5 would favour phosphate precipitation, whereas a higher $\mathrm{pH}(9-11)$ would favour carbonates. At dissolved concentrations higher than $20 \mu \mathrm{mol} / \mathrm{L}$ (which is the case at all industrial sites), $\mathrm{P}$ is assumed to inhibit calcite or aragonite precipitation [34]. In this study, $\mathrm{P}$ and $\mathrm{Ca}$ concentrations measured in the liquid phase were relatively similar in all industrial reactors but $\mathrm{pH}$, and alkalinity, was slightly higher at site 2 . The simultaneous presence of carbonate or phosphate in the same reactor was also possibly due to local heterogeneities. Therefore carbonate would preferentially precipitate in granules, where the microbial activity would induce the right $\mathrm{pH}$ for carbonate deposition (or in zones were alkalinity accumulated). In contrast with calcium precipitates, no significant magnesium phosphate or magnesium carbonate was observed in the microbial granules. The case of struvite deserves particular attention. Struvite was never found in the granules despite the high concentration of ammonium and phosphorus in the anaerobic effluents. It was thermodynamically under-saturated in all of the liquid phases of the (aerobic or anaerobic) processes studied, due to relatively low magnesium concentration in the effluents. This can also be explained by the fact that $\mathrm{pH}$ in the UASB was not high enough to permit struvite precipitation. In contrast, struvite crystal formation was systematically observed in the UASB supernatant sample after aeration, during which $\mathrm{pH}$ rose to 8 due to carbon dioxide stripping (results not shown). Therefore struvite was observed in the supernatant of UASB granular sludge only when a transient $\mathrm{pH}$ increase was generated [26].

It must also be noted that either CAL or ARAG was supersaturated in the GSBR (sites 4 and 5), whereas no calcium carbonates were found in the aerobic granules. This indicated either (1) the possible effect of precipitation inhibitors (e.g. phosphates coming from the EBPR process), or (2) ARAG or CAL precipitation in another zone (reactor walls, recirculation pipes) but not in the microbial granules. Another possibility would be the precipitation of calcium carbonate in the liquid phase, with possible nucleation on suspended solids or free bacteria (flocs), but this has not been demonstrated.

Regarding precursors of HAP in aerobic granules, the SI of calcium phosphates (DCPD, DCPA, HDP, ACP, TCP and HAP) decreased in all the aerobic systems, which can be explained by the precipitation of some of these compounds, also confirmed by previous granule analysis. Similarly, in the case of the anaerobic sites, it seems that HDP precipitation is to be discarded, contrary to the assumption of Maurer et al. [29].

\subsection{Location of mineral bioliths: a possible role of microbial reactions?}

The discussions above suggest that another important aspect is the location of the inorganic deposits in the different granular sludge processes. By modelling calcite precipitation, Langerak and co-workers [8] established different physical or chemical conditions for operating a UASB favouring precipitation in the liquid phase rather than in granules: 1) a low $\mathrm{Ca}$ :Na ratio; 2) small granule diameter; 3) a high mineral crystallization rate constant; and 4) an influent [Ca2+] $<390 \mathrm{mg} / \mathrm{L}$. In our case, information provided about the industrial effluents of the different sites and the number of samples were not sufficient to confirm most of these statements (Ca:Na, granule size, etc.). However, from a general point of view, the location of mineral crystals certainly depends on both physicochemical and biological phenomena. The major one, as stated by Langerak et al., is probably the crystallization rate constant.

It should be noted that the mineral crystallization rate of HAP is clearly lowest in calcium phosphate according to the literature, and this form was shown to accumulate in the core of granules here. In contrast, the other forms (ACP, TCP, OCP), which could be formed rapidly, were mainly observed at the periphery of aggregates, and could also be formed rapidly in the supernatant [37]. A first example was provided by the 'white' granules from UASB site 1 (S1_ana\#01 and S1_ana\#02), in which a mineral concretion was precipitated at the surface (ACP or TCP). This was also illustrated by the detailed analysis of granules from GSBR (sites 4 and 5), revealing that Ca:P ratios similar to those of HAP were mainly found in the central part of granules whereas more unstable but more rapidly formed phases (ACP, TCP, OCP) were found at the periphery.

Precipitation can be also related to the local conditions imposed by microbial reactions. Bacterial activity contributes to biomineralization by modifying local super-saturation, because ion and proton exchanges in 
the environment generate some gradients within the bio-aggregates. The spatial distribution of mineral clusters in the granules seems to show that local conditions in the core of microbial granules are favourable for calcium phosphate accumulation (especially HAP). Another observation (Figure 2) is that, for granules from aerobic reactors (GSBR), precipitates (bioliths) are found in the central part of the aggregates, whereas they are randomly distributed in the granules from anaerobic processes (UASB). A possible explanation is that local microbial modification of $\mathrm{pH}$, and carbonate and phosphate concentrations could encourage this precipitation.

According to microbial analysis over cross-sections of anaerobic granules [38,39], these bacteria are stratified as follows: acidogens are located in the outer part of the granules, while acetoclastic methanogens tend to form clusters in the central part. Hydrolysis, acidogenesis and acetogenesis release protons, while methanogenesis consumes protons $\left(0.25 \mathrm{mmolH}^{+}\right.$release $/ 1 \mathrm{mmol}$ acetate or $\mathrm{H}_{2}$ uptake). These observations lead us to think that a $\mathrm{pH}$ increase in the environment of methanogen clusters could generate favourable conditions for precipitation.

Similarly, in aerobic granular sludge processes, whereas nitrification takes place in aerobic zones of granules, denitrification consumes protons in their anoxic zones $[11,12]$. Calcium phosphate precursors initially formed at the periphery are progressively converted into a stable form (HAP) in the core. Further work would be necessary to discover how microbial reactions could modify the local $\mathrm{pH}$ and so play a role in this precipitation phenomenon. In addition, another possible interaction would be due to polyphosphate accumulating bacteria (PAO), whose ability to release phosphate during anaerobic periods transiently increases the calcium phosphate saturation in their environment.

\subsection{Consequences of precipitation}

From a general point of view, the role of biomineralization in microbial functions remains a matter of debate. Some authors maintain that it is the accidental effect of a metabolic by-product that can cause cell disruption [40], while others are convinced that it is a specific process with ecological benefits, such as providing better strength and resistance [41-43]. Accident or not, this phenomenon is reported to contribute favourably to the bioremediation field, where several applications for ion removal from wastewaters can be highlighted: removal of heavy metals from groundwater [44], and removal of radionucleotides [45] and calcium [46] from water.

In aerobic GSBR, the biomineralization of calcium phosphates is a side process of dephosphatation that takes place simultaneously in these aggregates, contributing to an increased settling velocity and to the P removal yield [13]. Encouraging the precipitation inside granules instead of in the liquid phase could lead to other advantages, such as the ability to control spontaneous precipitation in pipelines and on walls, thus reducing fouling and operating costs [9]. Langerak [17] found that, in anaerobic processes, the development of a high ash content in sludge contributed to biomass cementation and stabilization, which is an important parameter for operating UASB reactors. However, this process should be accurately controlled as negative consequences have also been reported. Kettunten and Rintala [47] noted losses of biomass methanogenic activity with high ash content in the sludge, constituting a deterrent for the long-term stabilization of UASB reactors. In the industrial cases studied, when precipitation took place at the surface of the aggregates the methane production efficiency decreased, and the UASB reactor had to be restarted with new granules if sludge was not extracted regularly. In our case, both UASBs containing the higher SMF sludge were found to

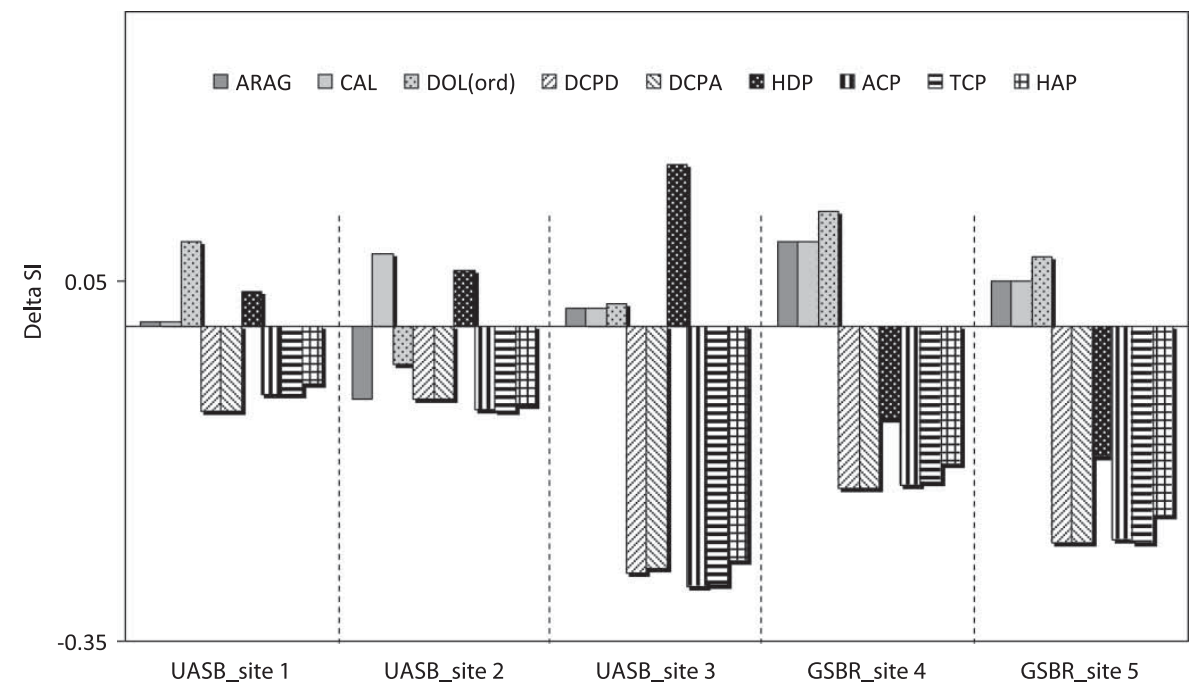

Figure 6. $\Delta$ SI for the different minerals that can precipitate in the different reactors considered. 
lose removal efficiency and thus needed to be restarted with fresh granules. This stresses the importance of removal efficiency losses relative to the bioavailability losses that occur at higher mineral fractions. At aerobic site 5, the sludge mineral content was also relevant (68\%), and some instability problems (VSS decrease) were noted.

SEM observations of the mineral fraction of aerobic granules revealed a porous honeycomb structure as can be seen in Figure 6.

The holes in the bioliths may have been due to bacterial colonies that disappeared (the diameters of the small holes in Figure $6 \mathrm{~b}$ are evocative of the pore sizes that would be produced by such a phenomenon) or may have been formed by gaseous metabolite exchanges $\left(\mathrm{CO}_{2}, \mathrm{~N}_{2}\right.$, etc.). Thus, a compromise should be adopted and regular granule extraction ensured in order to operate stable, efficient GSBR systems. Thermo-chemical databases can be used to estimate SIs and give an indication of the precipitation potential. Nevertheless, predicting the location of precipitation is still a complex task involving both physicochemical driving mechanisms (kinetics) and microbially induced phenomena. Two recent reviews highlight some of the proteins and enzymes involved in biogenic mineral formation in bacteria $[48,49]$. From a modelling point of view, more work will be needed before we are able to predict the exact calcium phosphate precursors that finally form HAP and to control microbially induced phosphorus precipitation (MIPP) through the operating conditions in the reactor.

\section{Conclusions}

Local analysis of mineral precipitation in microbial granules from anaerobic and aerobic reactors allowed the following conclusions to be drawn:

- Calcium phosphates were the major precipitates found in the granules. SEM-EDX analysis demonstrated that their solid composition was close to those of hydroxyapatite (HAP), amorphous calcium phosphate (ACP) or tricalcium phosphates (TCP). This was consistent with the analysis of the SI in the liquid phase, which indicated that these minerals were systematically saturated in the liquid phase.

- Calcium carbonate was only found in the granules from the anaerobic UASB 2 with the highest operating $\mathrm{pH}$ (treating industrial wastewater). Struvite was not found in the granules and it was thermodynamically under-saturated in all the processes studied, whether they were aerobic or anaerobic.

- The spatial distribution of mineral clusters in the aerobic granules seemed to indicate that local conditions in the core of microbial granules were favourable for calcium phosphate accumulation (especially HAP), whereas other minerals (such as calcium carbonates) tended to appear in the supernatant. Results also indicate that calcium phosphate precursors initially formed at the periphery were progressively converted into a more thermodynamically stable form (hydroxyapatite) on the core. These phenomena could be explained not only by differences in the crystallization kinetics but also by the local $\mathrm{pH}$ modification within the granules due to microbial activity (anaerobic or anoxic).

To sum up, the supernatant composition can help to predict the nature of the bioliths developed in granular sludge, but it is not the sole determining factor as it does not explain the differences found among granules grown in the same reactor. This emphasizes the role of microbial reactions in all the mechanisms contributing to the biomineralization phenomenon.

\section{Acknowledgements}

The authors would like to thank the VALBIO Company and especially D. Auban for his helpful contribution to this work.

\section{References}

[1] Water Research Commission Report, Water Wheel, Sept/Oct., (2008), pp.14-17.

[2] R.L.G. Lemaire, Development and fundamental investigations of innovative technologies for biological nutrient removal from abattoir wastewater, $\mathrm{PhD}$. diss., Advanced Water Management Centre, Brisbane, University of Queensland, 2007.

[3] G. Lettinga, A.F.M. van Nelsen, S.W. Hobma, W. de Zeeuw, and A. Klapwijk, Use of the upflow sludge blanket (USB) reactor concept for biological wastewater treatment, especially for anaerobic treatment, Biotechnol. Bioeng. 22 (1980), pp. 699-734.

[4] P. van Rensburg, E.V Musvoto, M.C. Wentzel, and G.A. Ekama, Modelling multiple mineral precipitation in anaerobic digester liquor, Water Res. 37 (2003), pp. 3087-3097.

[5] Y. Liu and J.-H. Tay, The essential role of hydrodynamic shear force in the formation of biofilm and granular sludge, Water Res. 36 (2002), pp. 1653-1665.

[6] M.K. De Kreuk, J.J. Heijnen, and M.C.M. van Loosdrecht, Simultaneous COD, nitrogen and phosphate removal by aerobic granular sludge, Biotechnol. Bioeng. 90 (2005), pp. 761-769.

[7] G. Yilmaz, R. Lemaire, J. Keller, and Z. Yuan, Effectiveness of an alternating aerobic, anoxic/anaerobic strategy for maintaining biomass activity of BNR sludge during long-term starvation, Water Res. 41 (2007), pp. 2590-2598.

[8] E.P.A. van Langerak, H. Ramaekers, J. Wiechers, A.H.M. Veeken, H.V.M. Hamelers, and G. Lettinga, Impact of location of $\mathrm{CaCO} 3$ precipitation on the development of intact anaerobic sludge, Water Res. 34 (2000), pp. 437-446.

[9] J. Borgerding, Phosphate deposits in digestion systems, J. Water Pollut. Control Fed. 44 (1972), pp. 813-819.

[10] A. Mañas, M. Spérandio, and B. Biscans, Etude de la précipitation du phosphore induite par réaction biologique dans un procédé de traitement d'effluent industriel par granulation aérobie, APTEN Conference, Poitiers, France, 2010.

[11] J.Wan, Y. Bessière, and M. Spérandio, Alternating anoxic feast/aerobic famine condition for improving granular sludge formation in sequencing batch airlift reactor at reduced aeration rate, Water Res. 43 (2009), pp. 5097-5108. 
[12] A. Mañas, M. Spérandio, and B. Biscans, Phosphorous recovery by inducing mineral phosphate precipitation in aerobic granular sludge process, Société Française de Génie des Procédés SFGP, Marseille, France, 2009.

[13] A. Mañas, M. Spérandio, and B. Biscans, Biologically induced phosphorus precipitation in aerobic granular sludge process, Water Res. 45 (2011), pp. 3776-3786.

[14] K. Svardal, Calcium carbonate precipitation in anaerobic waste water treatment, Water Sci. Techn. 23 (1991), pp. 1239-1248.

[15] T.T. Ren, L. Liu, G.P. Sheng, X.W. Liu, H.Q. Yu, M.C. Zhang, and J.R. Zhu, Calcium spatial distribution in aerobic granules and its effects on granule structure, strength and bioactivity, Water Res. 42 (2008), pp. 3343 3352.

[16] H.L. Wang, G.L. Yu, G.S. Liu, and F. Pan, A new way to cultivate aerobic granules in the process of paper-making wastewater in a sequencing batch reactor, Biochem. Eng. 28 (2006), pp. 99-103.

[17] E.P.A. van Langerak, Influence of phosphate and iron on the extent of calcium carbonate precipitation during anaerobic digestion. Control of Calcium Carbonate Precipitation in Anaerobic Digestion, Ph.D diss., Wageningen Agricultural University, The Netherlands, 1998.

[18] Z. Iqbal Bhatti, K. Furukawa, and M. Fujita, Comparative composition and characteristics of methanogenic granular sludges treating industrial wastes under different conditions, J. Ferment. Bioeng. 79 (1995), pp. 273-280.

[19] Q.S. Liu, Y. Liu, S.T.L. Tay, K.Y. Show, V. Ivanov, B.Y.M. Moy, and J.H. Tay, Startup of pilot-scale aerobic granular sludge reactor by stored granules, J. Envir. Tech. 26 (2005), pp. 1363-1370.

[20] AFNOR, 1994. Recueil des normes françaises: Qualité de l'eau, Environnement, Paris. Association Française de Normalisation.

[21] C.A. Paraskeva, P.C. Charalambous, L.E. Stokka, P.G. Klepetsanis, P.G. Koutsoukos, P. Read, T. Ostvold, and A.C. Payatakes, Sandbed consolidation with mineral precipitation, J Colloid Interface Sci. 232 (2000), pp. 326-339.

[22] L. Montastruc, Modélisation et optimisation d'un réacteur en lit fluidisé de déphosphatation d'effluents aqueux, $\mathrm{Ph} . \mathrm{D}$. diss., INPT, Toulouse, France, 2003.

[23] NIST database: Searchable bibliography of Fundamental Constants. Available at: http://www.nist.gov/pml/data/ physicalconst.cfm (consulted on January 2011).

[24] P. Wang, A. Anderko, R.D. Springer, J.J. Kosinski, and M.M. Lencka, Modeling chemical and phase equilibria in geochemical systems using a speciation-based model, J. Geochem. Explor. 106 (2010), pp. 219-225.

[25] R.P. Shellis and R.M. Wilson, Apparent solubility distributions of hydroxyapatite and enamel apatite, J. Colloid Interface Sci. 278 (2004), pp. 325-332.

[26] K.N. Ohlinger, T.M. Young, and E.D. Shroeder, Predicting struvite formation in digestion, Water Res. 32 (1998), pp. 3607-3614.

[27] K. Murray and P.M. May, Joint Expert Speciation System (JESS). An international computer system for determining chemical speciation in aqueous and non-aqueous environments, Supplied by Murdoch University, Murdoch, Western Australia and the Division of Water Technology, CSIR, Pretoria, South Africa, 1996.

[28] M. Frèche, Contribution à l'étude des phosphates de calcium, Ph.D. diss., INPT, Toulouse, 1989.

[29] M. Maurer, D. Abramovich, H. Siegrist, and W. Gujer, Kinetics of biologically induced phosphorus precipitation in wastewater treatment, Water Res. 33 (1999), 484493.
[30] B. Demirel, O. Yenigun, and T. Onay, Anaerobic treatment of dairy wastewaters: A review, Process Biochem. 40 (2005), pp. 2583-2595.

[31] A. Mañas, Study and modelling of phosphorus removal and recovery processes for agro-food wastewater treatment and valorization with aerobic granules, Ph.D diss. in course, 2011, LGC/LISBP, Toulouse, France.

[32] A. Mañas, M. Pocquet, B. Biscans, and M. Spérandio, Parameters influencing calcium phosphate precipitation in granular sludge sequencing batch reactor, Chem. Eng. Sci. (2012) In press (DOI :10.1016).

[33] R. Gao, F.E.D. van Halsema, E.J.M. Temminghoff, H.P. van Leewen, H.J.F. van Valenberg, M.D. Eisner, M. Giesbers, and M.A.J.S. van Boekel, Modelling ion composition in simulated milk ultrafiltrate (SMUF). I: Influence of calcium phosphate precipitation, Food Chem. 122 (2010), pp. 700-709.

[34] L.J. Plant and W.A. House, Precipitation of calcite in the presence of inorganic phosphate, Colloids Surf., A 203 (2002), pp. 143-153.

[35] W.A. House, Inhibition of calcite crystal growth by inorganic phosphate, J. Colloid Interface Sci. 119 (1987), pp. 505-511.

[36] P. Battistoni, G. Fava, P. Pavan, A. Musacco, and F. Cecchi, Phosphate removal in anaerobic liquors by struvite crystallization without addition of chemicals: Preliminary results, Water Res. 31 (1997), pp. 2925-2929.

[37] A. Mañas, M. Pocquet, B. Biscans, and M. Spérandio, Parameters influencing calcium phosphate precipitation in granular sludge sequencing batch reactor, In course of submission at Chemical Engineering Science, 2011.

[38] D.J. Batstone, C. Picioreanu, and M.C.M. van Loosdrecht, Multidimensional modelling to investigate interspecies hydrogen transfer in anaerobic biofilms, Water Res. 40 (2006), pp. 3099-3108.

[39] J. Quarmby and C.F. Forster, An examination of the structure of UASB granules, Water Res. 29 (1995), pp. 2449-2454.

[40] H.V. Knorre and W.E. Krumbein, Bacterial calcification in microbial sediments, Springer-Verlag, Berlin, 2000, pp. 25-31.

[41] H. Ehrlich, Geomicrobiology: its significance for geology, Earth Sci. Rev. 45 (1996), pp. 45-60.

[42] T.A. McConnaughey and J.F. Whelan, Calcification generates protons for nutrient and bicarbonate uptake, Earth Sci Rev. 42 (1997), pp. 95-117.

[43] T.J. Beveridge, Role of cellular design in bacterial metal accumulation and mineralization, Ann. Rev. Microbial. 43 (1989), pp. 147-171.

[44] L. Warren and E. Haack, Biogeochemical controls on metal behaviour in freshwater environments, Earth Sci. Rev. 54 (2001), pp. 261-320.

[45] Y. Fujita, G.D. Redden, J.C. Ingram, M.M. Cortez, F.G. Ferris, and R.W. Smith, Strontium incorporation into calcite generated by bacterial ureolysis, Geochim. Cosmochim. Acta 68 (2004), pp. 3261-3270.

[46] F. Hammes, N. Boon, J. Villiers, W. Verstraete, and S.S. Douglas, Strain-specific ureolytic microbial calcium carbonate precipitation, Appl. Environ. Microbiol. 69 (2003), pp. 4901-4909.

[47] R.H. Kettunen and J.A. Rintala, Performance of an on-site $U A S B$ reactor treating leachate at low temperature, Water Res. 32 (1998), pp. 537-546.

[48] S. Weiner, Biomineralization: A structural perspective. J. Struct. Biol. 163 (2008), pp. 229-223.

[49] W. De Muynck, N. de Belie, and W. Verstraete, Microbial carbonate precipitation in construction materials: A review. Ecol. Eng. 36 (2010), pp. 118-136. 